\title{
Halal Certification Procedures: Some Unresolved Issues
}

\author{
Marco Tieman*
}

There is a higher halal awareness among Muslim consumers, where the product in the supermarket is no longer assumed halal and its halal certificate and country of origin are more and more checked for the acceptance of and trust in new products. New Islamic brands are emerging in Muslim markets that are taking significant market share from conventional big foreign brands in both food and cosmetics. These Islamic brands have been classified by Alserhan ${ }^{1}$ as true Islamic brands as these brands are Shariah-compliant, they originate from an Islamic country and their target is the Muslim consumer. Halal scandals over the past years have proven the vulnerability of halal food supply chains and the possibility of a halal issue to escalate into a major crisis for brand owners.

Halal certification has a relatively short history, which started in Malaysia in the 1980's and expanded to other countries and also to other products and services since. Today there are more than 400 known halal certification bodies (HCBs). ${ }^{2}$ As a result, there are many different halal standards: local standards (either developed by a national standards development body or by the HCB itself), regional standards (e.g. the Arab Gulf Cooperation Council's halal standard) and international halal standards (IHI Alliance and SMIIC). The HCB provides auditing and certification services for which it charges either a fixed or a volume based fee. It is a product certification, addressing especially the ingredients and production process, which allows the producer to put a halal logo of the HCB on the product packaging. This logo communicates to the Muslim consumer that the product is halal certified according to the halal standard of the respective HCB.

These halal product standards are not static and through revisions could include requirements for first tier suppliers and customers in terms of transportation and storage. Some halal standards and certification bodies are also creating dedicated halal standards for logistics, food services, retail, and others; allowing halal producers to make the supply chain halal compliant through the adoption of local, regional and/or international halal standards. Halal regulations are further strengthened by Muslim countries in the Middle East and Asia for imports. New regulations are prescribing more products that require a halal certificate (for example: dairy ingredients, plant based extracts) as well as the recognition by the importing country of a selected number of HCBs in the world that can issue these certificates. 
For the Muslim consumer the halal status is important at the point of consumer purchase as halal is a religious obligation. A halal logo on the product is a promise of the brand owner that the product is halal at the point of consumer purchase. A neglect of halal requirements throughout the entire supply chain is gradually weakening consumer confidence in halal brands. This halal assurance gap in distribution presents an increasing (reputation) risk for brand owners.

Many brand owners regard halal certification as a problem: a necessary compliance issue in order to sell to Muslim markets. It is not seen as an integral business philosophy addressing the entire supply chain (namely: sourcing, production and distribution) or even its value chain (including Islamic branding, financing, sustainability) as a whole. This makes companies rather following halal regulation instead of being proactive in developing their halal supply chain or value chain. As brand owners have regarded halal as (an ingredient and production) compliance issue, they have not addressed halal compliance with their supply chain partners (with the exception of producers of halal ingredients), as it was not required for certification. The result is that logistics service providers and traders are far behind in halal assurance and few are halal certified today.

The logistics service provider is an important partner in the supply chain responsible for transportation, warehousing and value added logistics (like copacking for promotions). He consolidates good flows to ensure high utilisation of assets and minimises costs. However, halal has traditionally not been a criterion in consolidating cargo flows in transportation and storage. The result is that lessthan-container and less-than-truck loads could mix halal and non-halal products in transportation, and warehousing could mix halal and non-halal products in storage.

The wholesaler and distributor provide a local stock point for a wide range of products sourced from all over the world, to support local retail and restaurants. Often these wholesalers and distributors are not dedicated to one brand and could even carry both halal and non-halal products in their product range. In their warehouse they could mix both halal and non-halal products. Wholesales and distributors could have their own trucks to transport these products to the retail and restaurants as and when demanded by their customers. However, many traders have outsourced their transportation requirements. Halal has traditionally not been a criterion in transportation. As the individual deliveries could be small, so-called milk-runs (combining several drop points and collection points in one trip) are often used to minimise transportation costs. As a result halal and nonhalal goods could be mixed in transportation to retail.

In modern trade, large retail chains could have a distribution centre to consolidate shipments from manufacturers and wholesalers to their supermarkets in order to minimise number of truck deliveries to one supermarket. This could 
result in mixing of halal and non-halal products, as halal often is not a criterion in consolidation for distribution to retail. The traditional supermarkets are delivered by various wholesalers and distributors, which could add up to many trucks bringing goods to these shops during a day. The retailer provides access of products sourced from all over the world to the final customer, both halal and non-halal products. Various supermarkets in Muslim countries have created a dedicated non-halal zone, clearly marked as such, for the sales of alcoholic drinks and pork products. This non-halal zone could have their own cashier, avoiding the risk of contamination on the supermarket cashier counter belt by non-halal products, and different trolleys. On the other hand, a number of supermarkets in non-Muslim countries have created a dedicated halal zone, clearly marked as such, for the sales of halal (meat) products and other ethnic products from (major immigrant) Muslim countries. As a non-Muslim country might host Muslims from different parts of the world, and as a consequence different halal requirements, it is difficult to please all Muslims as the halal meat requirements could be different. This has resulted in challenges in offering the 'right' halal assortment for supermarkets in non-Muslim countries that were trying with the right intention to serve the Muslim consumer.

Recent halal scandals have shown that a narrow view of halal certification by brand owners exposes the company and its brands in Muslim markets. Although current halal standards do not prescribe halal certification of the entire supply chain, brand owners should extend halal assurance towards supply chain management in order to protect their brand better. Halal assurance should by design cover sourcing, production and distribution. The purchasing function needs to be redefined in ensuring an effective alignment between halal policy, procurement strategy and purchasing process. ${ }^{3}$ Contingency plans should be drafted to allow for easy switch to other suppliers. The purchasing function plays therefore a key role in the design of more robust supply chains. In distribution, the company should address halal assurance towards to point of consumer purchase, including its logistics service providers, wholesalers, distributors and retailers. Halal should be covered in contracts and a criterion in logistics. Furthermore a solid crisis management team should be assembled to handle halal issues quickly and adequately and have a short communication channel with its halal certification body.

Governments and HCBs should extend halal requirements towards supply chain management for halal certification of producers and restaurants, as a narrow perspective, limited to ingredients and production, highly exposes the company in today's market place. For this HCBs should promote halal certification of supply chain parties, in particular the logistics service provider, traders and retailers. As logistics service providers deal with international movements, it is important 
for HCBs to adopt the international halal logistics standard (IHIAS 0100:2010) in order to make international supply chains fully aligned and consistent. As supply chains today are global, the use of a different local halal logistics standard that is not aligned with the international halal logistics standard would create inconsistencies in the supply chain by definition in halal transport, storage and terminal handling practices, endangering the integrity of the entire halal supply chain. For trade and retailers new halal standards possibly need to be developed as existing local halal standards might not be applicable to them or create serious problems in the implementation, limiting the adoption rate of the halal standard by traders and retailers.

A better insight into the perception of the Muslim consumer regarding its halal supply chain and halal value chain requirements is critical for the halal industry and HCBs. This requires support from governments and universities in funding this type of research.

\section{Notes}

* Dr. Marco Tieman is Adjunct Professor with Universiti Tun Abdul Razak (Malaysia), responsible for research in halal supply chain management. He is also Adjunct Professor with Universiti Malaysia Pahang (Malaysia). He obtained his Master's degree in industrial engineering [logistics] with the University of Twente (the Netherlands) in 1997 and his PhD in business management [halal supply chain management] with Universiti Teknologi MARA (Malaysia) in 2013. $\mathrm{He}$ is also the CEO of LBB International, an international logistics consultancy and research firm specialised in halal purchasing and supply chain management. He chaired the development of the international halal logistics standard (IHIAS, 0100:2010) under ICCI-IHI Alliance. Dr. Marco Tieman is the corresponding author and can be contacted at: marco@lbbinternational.com

1. Alserhan, Baker Ahmad. "On Islamic branding: brands as good deeds." Journal of Islamic Marketing, Vol. 1, no.2 (2010): 101-106.

2. HalalFocus (2014), OIC to establish one global halal standard, 2 May 2014, available at: http://halalfocus.net/oic-to-establish-on-global-halal-standard/ (accessed 2 October 2014)

3. Marco Tieman, "Principles in halal purchasing." Journal of Islamic Marketing, Vol. 4, no. 3 (2013): 281-293. 